\title{
Can Text Analysis Tell us Something about Technology Progress?
}

\author{
Khurshid Ahmad \\ Department of Computing \\ University of Surrey, Guildford, \\ Surrey. GU2 7XH. UK \\ k.ahmadesurrey.ac.uk
}

\author{
AbdulMohsen Al-Thubaity \\ Department of Computing \\ University of Surrey, Guildfor d, \\ Surrey. GU2 7XH. UK \\ a.althubaityesurrey.ac.uk
}

\begin{abstract}
A corpus-based diachronic analysis of patent documents, based mainly on the morphologically productive use of certain terms can help in tracking the evolution of key developments in a rapidly e volving specialist field. The patent texts were o btained from the US Patent \& Trade Marks Office's on-line service and the terms were extracted automatically from the texts. The chosen specialist field was that of fast-switching devices and systems. The method presented draws from liter ature on biblio - and sciento -metrics, information extraction, corpus linguistics, and on aspects of English morphology. This interdisciplinary fram ework shows that the evolution of word-formation closely shadows the developments in a field of technology.
\end{abstract}

\section{Introduction}

A patent document is written to pe rsuade a technolegal authority that the patentee should be allowed to manufacture, sell, or deal in an article to the exclusion of other persons. The article is typ ically based on an invention that the patentee(s) claim has been theirs. The term article is important in that it refers to a tangible object and its $u$ sage is to emphasise that ideas, intangibles essentially, ca nnot be patented. Patent documents are the repos itory of how technology advances and, more importantly, show how language supports the change.

The techno-legal authority requires the patent document to follow a template. This template is divided broadly into two parts: first, legal te m- plates comprising pate ntee's details, juri sdictional scope, and related item; second, technical templates divided into a summary of the patentee's claims, relation of the article to previously patented articles - the so-called prior art - and the scientific/technical basis of the claim. The scientific claim is written in a language that is similar to the language of journal $p$ apers.

One important task that is slowly emerging is the extent to which the analysis of a patent doc ument can be automated particularly to a ssess the overlap between the claims in the document about the article to be patented with that of related, rel evant and even counter-claims about the article. The related and rel evant claims and counter claims may be found in existing patent documents and may, more in directly, exist in journal papers.

A patent document has to make references to all other relevant/related articles that have been patented prior to the invention of the art icle, which is yet to be patented and is the object of the patent document. The ref erences are made primarily by citing the name of the prior art patentees and the titles of their patent documents. A patent doc ument also has other linguistic descriptions of prior art; such descriptions are reminiscent of citations of journal papers in a journal paper. The overlap of a new patent document with a set of existing patent documents may suggest the impact of extant knowledge in patent documents on emerging knowledge in the new patent document. Such an overlap has been studied by the impact of US semiconductor technology on the rest of the world (Appleyard and Kalsow: 1999): this overlap relies largely on the frequency of citation of a US patent by the name of its author or the author's place of work. In computational linguistic (CL) terms thi s exercise relies on proper noun extra ction.

The patent document relates to an explicit and exclusive right over an intellectual property. A journal article relates to an implicit and i nclusive 
right over an intellectual property. The overlap between the se two forms of claims is crucial not only in ascertaining the rights of the patentee, or the abuse of the rights of others by the pa tentee, but also for monitoring the effectiveness of $\mathrm{r}$ esearch based on a specialism as a whole or that of its component gro ups.

The effect of one author or a group of authors working in an institution is indirectly mea sured by the so-called impact factor. This factor relates to the frequency of citation of one or more journal papers written by an author or by a group. The calculation of the impact fa ctor relies mainly on computing the frequency of the authors' name(s) within a corpus of journal articles. Such an impact factor type calculation is used typically in bibl $\mathrm{i}$ ometrics (Garfield 1995). Again, as in intra -patent impact studies mentioned above, in CL terms this is an exercise in proper noun identification and extraction.

The analysis of a patent document, together with the analysis of the related corpora of other patent documents and intellectual property doc uments, should be based on a framework which provides methods and tec hniques for analysing the contents of the document and of the corpora. For us the source of a framework still lies in li nguistic and language studies. Here we are pa rticularly interested in word formation and terminology u sage in highly specialised disc iplines particularly those disciplines that deal with inta ngible articles coupling the word formation and terminology u sage with the citation patterns of proper nouns brings us closer to analysing the contents of a patent document and its siblings distributed over co $\mathrm{r}$ pora.

Information scientists usually use the referen cing data of research documents to analyse know 1edge evolution in scientific fields as well as to identify the key authors, institutes, and journals in specific domains, using tools such as publication counts, citation analysis, co-citation analysis, and co-term analysis to do so. In recent years, patent documents have gained considerable attention as a valuable resource that can be use $\mathrm{d}$ to analyse tec $\mathrm{h}$ nology advances using the same tools.

Gupta and Pangannaya (2000) have applied bibliometric analysis to carbon nanotube patents to measure the growth of activity of carbon nan otube industries and their links with sc ience. They have also used patents data to study the country -wise distribution of patenting activity for the USA, J apan, and other countries. Sector -wise performances of industry, academia and government, and the active players of carbon nanotubes were also stu died. They describe the nature of inventions taking place in this particular field of technology, and the authors claim to have identified the emerging $\mathrm{r}$ esearch directions, and the active companies and research groups involved.

Meyer (2001) has used citation anal ysis and co-word analysis of patent documents and sc ientific literature to explore the interrel ationship between nano-science and nano-technology. Meyer investigated patent citation relations at the orga nizational levels along with geographical locations and affiliations of inventors and a uthors. The term co-occurrence is used by Meyer to find the rel ationship between the patent documents and the two scientific liter ature databases SCI and INSPEC. He has noticed that '...the terms that occur frequently in the document titles of all databases are related to [...] instrumentalities and/or are located in fields that are generally associated with substantial indu strial research activity' (2001:177). Meyer has a rgued that 'Our data suggests that nano -technology and nano-science are essentially separate and he terogeneous, yet interrelated cumulative stru ctures' (2001:164).

The study of word formation through $\mathrm{n}$ eologisms within the special language of science and technology has led some authors to argue that it is the scientists as technologists who attempt to rationalise our experience of the world around us in written language by using new words or forms or by relexicalising the existing stock (see Ahmad 2000 for relevant references). Some lexicogr aphers (see for example Quirk et al. 1985) have su ggested that neologisms can be formed by two processes: First, the addition or combination of elements such as compounding: Resonant Tunne ling Diodes and Scanning tunneling microscopy are examples for this type of neologism (compoundin $\mathrm{g}$ as a neologism formation is used extensively in science and technology literature); Second, the $\mathrm{r}$ eduction of elements into abbreviated forms. The abbreviations FET (Field E ffect Transistor) and MOSFET (Metallic Oxide Semiconductor FET) are examples of this type.

Neologisms appear to signal the eme rgence of new concepts or artefacts and the frequency of this new word might indicate the scientific comm u- 
nity's acceptance of this new concept or artefact. Effenberger (1995) has argued that '... the faster a subject field is developing, the more novelties are constructed, discovered or created. And these no velties are talked and written about. In o rder to make this technical communication as efficient as possible, provision should be made for avoiding misunderstanding. One crucial point in this process is the vocabulary that is being used' (1995:131, emphasis added).

In this paper we discuss the idiosyncratic la nguage used in patent documents. The language is replete with terms and there are instances within a patent document that suggest that the authors not only use the specialist terms but use a local syntax as well. We look specifically at the structure of the US Patents and suggest how with existing tec $\mathrm{h}$ niques used in information extraction and NLP, including term extraction and proper noun identif $\mathrm{i}$ cation, one can perform fairly complex tasks in patent analysis - some of which are performed by patent experts by hand currently (Section 2). This examination suggests to us a model of develo pment in computer and semi-conductor technology: an incremental model where each subsequent pa tent helps in the development of ever -complex artifacts - starting from devices onto circuits and onto systems. We will look at one of the key i nventions in the field of semiconducto rs physics - the electron tunneling device. These devices co mbine technical elegance, experimental complexity and manufacturing challenge. Due to its strategic i mportance, a number of patents have been o btained by the US government and also by a nu mber of US and Japanese companies (Section 3). Section 4 concludes this paper.

\section{The Structure of US PTO Doc uments and a Local Grammar for the Docu- ments}

The USPTO database is a representative sa mple of patent documents. The USPTO has documents $\mathrm{r}$ elated to most branches of science and technology. It includes information about all US patent doc uments since the first pa tent issued in 1970 to the most recent. The USPTO database a llows the user to search the full text of the patent documents for a certain word or a co mbination of words. It also provides a field search for specific information such as inventor or assignee. The search can also be conducted for a sp ecific year or range of years. The US Patents are written partly as a legal text and partly as a scientific d ocument. Over the last 50 years or so, it appears that US Patent doc uments have been structured in terms of layout and have a superficial resemblance to Marvin Minsky's frame-like knowledge represe ntation schema.

The patent document can be divided into three main parts for the present discussion: The first part comprises the biographical details of the inventors (and their employers) together with the title of the invention and a brief free -text abstract, dates when the patent was applied for and when the patent was granted and so on. The free text is essentially a summary of the claims of the pa tentee; The second part contains external refe rences of three sorts: the first sort is the specialist domain of the invention - the subject class indica ting the super-ordinate class and instances; the se cond sort are other cited patents organised as a 4 -tuple: (i) patent number, (ii) date of approval, (iii) first i nventor and (iv) classification number; and, the third sort is a bibliographic reference to public ations that may have contributed to the pa tent; The third part of a current US Patent document co mprises 'claims' related to the patent and the $\mathrm{d}$ escription of the 'invention' (there are diagrams of the inve ntion attached to the document and the diagrams d escribed in the text). Table 1 on the next page shows the template of the current (c. 1980 and a fter) USPTO's.

The 'claims' of the patentees are clearly itemised and initialised by the number of the claim; the first claim is the basis of the patent abstract generally. The 'background to the invention' is written in an idiosyncratic fashion as well - the invention is first contextualised in a broader group of other inventions to date and then the specific nature of the invention is exemplified. The broader and the specific are usually marked by phrases like 'The (present) invention relates to' and the specificity is phrased as '(more) specif ically.' or '(more) pa rticularly'. These phrases are followed by one or more noun phrases connected with, for example, conjunctions or qualifiers. The first noun phrase names the article i nvented, for instance, a name of a new device, circuit or a fabr icating or testing pro cess. 


\begin{tabular}{|l|l|}
\hline FIELD & VALUE \\
\hline United States Patent Number & NUMBER \\
\hline First Inventor & PROPER NOUN ET AL. \\
\hline Date Patent Approved & DATE \\
\hline Title: & FRE TEXT \\
\hline Abstract: & FREE TEXT \\
\hline Inventors: & PROPER NOUNS \\
\hline Assignee: & PROPER NOUNS \\
\hline Application No.: & NUMBER \\
\hline Filed: & DATE \\
\hline Patent Classification Data: & NUMBER \\
\hline References Cited [Refe renced By]: & [PATENT NUMBER, DATE, FIRST INVENTOR, \\
\hline $\begin{array}{l}\text { Parent Case Text: } \\
\text { CROSS REFERENCE TO RELATED APPLICATION }\end{array}$ & CLASS NO.] \\
\hline Claims: & FRE TEXT \\
\hline $\begin{array}{l}\text { CLAIM 1: } \\
\text { CLAIM 2: }\end{array}$ & 'What is claimed is: ' \\
\hline Description & FORMULAIC FREE TEXT \\
\hline BACKGROUND OF THE INVENTION & FORMULAIC FREE TEXT \\
\hline 1. Field of the Inve ntion: & \\
\hline 2. Related Background Art: & FORMULAIC FREE TEXT \\
\hline SUMMARY OF THE INVENTION: & FORMULAIC FREE TEXT \\
\hline BRIEF DESCRIPTION OF THE DRAWINGS: & SEMI FORMULAIC FREE TEXT \\
\hline $\begin{array}{l}\text { DETAILED DESCRIPTION OF THE PREFERRED } \\
\text { EMBODIMENTS: }\end{array}$ & FRE TEXT \\
\hline
\end{tabular}

Table 1: A slot-filler template of the US PTO a pproved patent documents.

The NP comprises determiners and modal verbs together with (compound) nouns. The first NP is optionally followed by a qualification that restricts or extends the scope of the disco very - the enlargement or restriction is named and another NP is used for the naming and so on. This simple grammar can be verified by exa mining a corpus of patent documents. To illu strate this point we have looked at a recent randomly selected patent on memory devices - a patent filed by Kabushiki Kaisha Toshiba of Japan (or Toshiba for short), and approved by USPTO on $20^{\text {th }}$ May 2003, on a sem iconductor memory device which uses the emergent notion of memory cells (a memory cell is a tiny area within the memory array that actually stores the bit in the form of an electrical charge ${ }^{1}$ ). An analysis of the title and that of the 'Background of the Invention: Field of Invention' fields shows the use of this restricted syntax (Table 2). In much the

\footnotetext{
${ }^{1}$ Definition form http://rel.intersil.com/docs/lexicon/M.html, site visited 29 May 2003)
}

same as the 'claims' and 'the 'background', the 'summary of the invention' is also phrased in a formulaic manner (see Table 1 for the structure of the patent document).

The analysis of the other slots governed by a simpler grammar yields interesting results and suggests that the name $\mathrm{s}$ of assignees and the manner in which patents are being cited can be easily inter-related (Table 3). Toshiba's USPTO 6567330 refers to 8 other patents. The details of the referenced patents are in a 4 -tuple, which can be unambiguously interpreted. Each of the referenced patents refers to about 10 patents in turn. An examination of 82 such patents may help to initiate, perhaps, a discussion of the 'invention life cycle' or 'licen sing potential of a patent' (Mogee 1997), or even a discussion of 'micro fo undations of innovation systems' (Ande rsen 2000). 


\begin{tabular}{|c|c|c|c|}
\hline $\begin{array}{l}\text { Title } \\
\text { of the Patent }\end{array}$ & $\begin{array}{l}\text { US PTO } \\
\text { Number }\end{array}$ & \multicolumn{2}{|c|}{ Field of Invention } \\
\hline $\begin{array}{l}\text { Semiconductor memory } \\
\text { device }\end{array}$ & 6567330 & $\begin{array}{l}\text { The present invention relates to a semi- } \\
\text { conductor memory device with a current-read- } \\
\text { type memory cell }[\ldots]\end{array}$ & $\begin{array}{l}\text { More specifically, the present invention } \\
\text {-relates to a data sense circuit for the } \\
\text { semiconductor memor } y \text { device. }\end{array}$ \\
\hline \multicolumn{4}{|c|}{ Patents cited by USPTO $\underline{6567330}$} \\
\hline $\begin{array}{l}\text { Nonvolatile semiconduc- } \\
\text { tor memory device }\end{array}$ & $\underline{6407946}$ & $\begin{array}{l}\text { The present invention generally relates to a } \\
\text { nonvolatile semiconductor memory device, }\end{array}$ & $\begin{array}{l}\text { and more particularly relates to an electri- } \\
\text { cally erasable and programmable read } \\
\text { only memory }\end{array}$ \\
\hline $\begin{array}{l}\text { Semiconductor memory } \\
\text { device }\end{array}$ & 6337825 & $\begin{array}{l}\text { This invention relates to a semiconductor } \\
\text { memory device, }\end{array}$ & $\begin{array}{l}\text { and more particularly to a sense amplifier } \\
\text { of a nonvolatile semiconductor memory } \\
\text { using current read-out type memory } \\
\text { cells. }\end{array}$ \\
\hline $\begin{array}{l}\text { Memory cell sense ampli- } \\
\text { fier }\end{array}$ & $\underline{6219290}$ & $\begin{array}{l}\text { The present invention relates to memory ar- } \\
\text { rays, }\end{array}$ & $\begin{array}{l}\text { and in particular, the sensing of data } \\
\text { from a non-volatile memory cell. }\end{array}$ \\
\hline $\begin{array}{l}\text { Current conveyor and } \\
\text { method for readout of } \\
\text { MTJ memories }\end{array}$ & 6205073 & $\begin{array}{l}\text { This invention relates to M[agnetic] } \\
T \text { [unneling] J[unction] memories }\end{array}$ & $\begin{array}{l}\text { and more particularly, to apparatus and } \\
\text { a method for reading data stored in } \\
\text { MTJ memories. }\end{array}$ \\
\hline $\begin{array}{l}\text { Read reference scheme for } \\
\text { flash memory }\end{array}$ & $\underline{6038169}$ & This invention relates to flash memory & $\begin{array}{l}\text { and in particular to creating a reference } \\
\text { by which to read the state of flash mem- } \\
\text { ory cells. }\end{array}$ \\
\hline $\begin{array}{l}\text { Sensing circuit for a float- } \\
\text { ing gate memory device } \\
\text { having multiple levels of } \\
\text { storage in a cell }\end{array}$ & $\underline{5910914}$ & $\begin{array}{l}\text { The present invention relates to a sensing cir- } \\
\text { cuit for use with a memory array comprised of } \\
\text { floating gate devices, [...]. }\end{array}$ & $\begin{array}{l}\text { More particularly, the present invention } \\
\text { relates to the use of a plurality of invert- } \\
\text { ers to compare the current from a ref- } \\
\text { erence cell }[\ldots]\end{array}$ \\
\hline $\begin{array}{l}\text { Flash memory device } \\
\text { having a page mode of } \\
\text { operation }\end{array}$ & 5742543 & $\begin{array}{l}\text { The present invention relates generally to } \\
\text { memory devices }\end{array}$ & $\begin{array}{l}\text { and more particularly to a non volatile } \\
\text { memory device having a page mode of } \\
\text { operation. }\end{array}$ \\
\hline $\begin{array}{l}\text { Single cell reference } \\
\text { scheme for flash memory } \\
\text { sensing and program state } \\
\text { verification }\end{array}$ & 5386388 & $\begin{array}{l}\text { The invention relates to the field of metal- } \\
\text { oxide semiconductor (MOS) [..]EPROMS [..] }\end{array}$ & $\begin{array}{l}\text { particularly to the field of "flash" } \\
\text { EPROMs [..] }\end{array}$ \\
\hline
\end{tabular}

Table 2: The use of restricted syntax in the d escription of the generic and specific fields of inventi on. The higher patent number shows that it was filed at a later date than a lower patent number. So, the above figure shows a time o rder as well.

\begin{tabular}{|c|c|c|c|c|c|c|c|c|}
\hline Assignee & Country & $\begin{array}{c}\text { Patent } \\
\text { Number }\end{array}$ & $\begin{array}{c}\text { USPTO } \\
\text { Class }\end{array}$ & $\begin{array}{c}\text { Approval } \\
\text { Date } \\
\text { (a) }\end{array}$ & $\begin{array}{l}\text { Earliest } \\
\text { Reference } \\
\text { (b) }\end{array}$ & $\begin{array}{l}\text { Latest } \\
\text { Reference } \\
\text { (c) }\end{array}$ & $\begin{array}{l}\text { Invention } \\
\text { Cycle Time' } \\
\text { (a) - (c) }\end{array}$ & $\begin{array}{c}\text { Invention } \\
\text { Cycle Time", } \\
\text { (b) - (c) }\end{array}$ \\
\hline \multirow[t]{2}{*}{\begin{tabular}{|l|} 
Toshiba \\
\end{tabular}} & Japan & 6567330 & $365 / 210$ & May- 03 & Jan-95 & Jun-02 & 1.0 & 6.5 \\
\hline & Patents & cited & by & USPTO & Number & 6567300 & & \\
\hline Matshushita & Japan & 6407946 & $365 / 185$ & Jun-02 & Jun-93 & Nov-99 & 2.5 & 6.3 \\
\hline Toshiba & Japan & 6337825 & $365 / 185$ & Jan-02 & Nov-92 & Aug-00 & 1.5 & 7.3 \\
\hline Macronix & Taiwan & 6219290 & $365 / 185$ & Apr-01 & Aug-93 & May-98 & 3.0 & 4.8 \\
\hline Motorola & US & 6205073 & $365 / 171$ & Mar-01 & Jun-98 & Aug-00 & 0.5 & 2.1 \\
\hline Halo LSI & US & 6038169 & $365 / 180$ & Mar-00 & Dec-92 & Aug-99 & 0.8 & 6.8 \\
\hline Silicon Storage & US & 5910914 & $365 / 185$ & Jun-99 & Sep- 80 & Jun-97 & 2.0 & 17.0 \\
\hline Intel & US & 5742543 & $365 / 185$ & Apr-98 & Nov-96 & May-80 & 1.5 & 19.5 \\
\hline Intel & US & 5386388 & $365 / 185$ & Jan-95 & May-72 & Dec-92 & 2 & 19.5 \\
\hline
\end{tabular}

Table 3: A glimpse of the technology transfer in the Toshiba patent for 'data sensing circuits' for sem iconductor memory de vices. The US Patent Classification 365 refers to 'Static Information Storage and Retrival, and the subclassifc ations 185 \& 171 refer to 'Floating Gate Memories' \& 'Magnetic Thin Films' 
A finer grained analysis to show which 'country' is more influentia 1 can also be performed fairly readily and indicates the extent to which pa tents that are held by assignees domiciled in the USA have over half the cited patents (Table 4).

\begin{tabular}{|l|r|c|l|r|c|}
\hline $\begin{array}{c}\text { Assignee } \\
\text { Country }\end{array}$ & $\#$ & \multicolumn{1}{c|}{$\%$} & $\begin{array}{c}\text { Assignee } \\
\text { Country }\end{array}$ & $\#$ & $\%$ \\
\hline US & 45 & $54.9 \%$ & Korea & 2 & $2.4 \%$ \\
\hline Japan & 18 & $22.0 \%$ France & 1 & \\
\hline Independent & 7 & $8.5 \%$ Germany, & 1 & $1.2 \%$ \\
\hline Italy & 5 & $6.1 \%$ & UK & 1 & \\
\hline Taiwan & 2 & $2.4 \%$ & TOTAL & $\mathbf{8 2}$ & $\mathbf{1 0 0}$ \\
\hline
\end{tabular}

Table 4: An analysis of USPTO No. 6567330 (T oshiba Japan) shows the major influence of US based assignees, followed by Japan. A significant number of patents $(8.5 \%)$ are held by individuals and not assigned specif ically to a country.

A semi-automatic analysis of terms used in the Abstracts and Titles of the patents (Toshiba 6567330 and patents referenced in the Toshiba patents) shows the co-citation pattern of terms. This may help in the clustering of patents on the basis of terms extracted from the patent doc uments as well as novel terms (terms not included in the USPTO Patent Class ification terminology data base) found in the doc ument. We show the cocitation of the two key terms memory cell and memory device in the nine patents discussed above. The use of the two terms individually and as roots and stems of other compounds is also shown. The more frequent citation is to the newer term memory cell and it is cited in all but one of the 9 related patents. The related memory devices - newer devices now incorporate memory cells - is less frequently used and it is only found in the abstracts of 5 out of the 9 patents. Both terms are co -cited in 6 out of the 9 patents (see Table 5 for details).

The interrelationship between the different patents can be explored further by examining closely as to what is being patented within the pa tent and what is being patented in the referenced patents. Again, we use the e xample of the Toshiba patent No. 6567330 which refers to 8 other patents. The patent itself relates to the invention of a system. The referred patents relate to other systems and circuits. Let us look at the earliest patent cited in Toshiba's patent: th is is US PTO No. 5386388 filed by Intel Corporation (USA) approved in
January 1995. The title of I ntel's patent is 'Single cell reference scheme for flash memory sensing and program state verific ation'. Flash memory is defined as 'A nonvolatile programma ble semiconductor memory product ${ }^{2}$. This patent $r$ elates to the invention of a circuit. Intel's patent comprises re ferences to another 15 patents: 5 refer to other sy stems, 8 to circuits, and one each to a device and a software program (see Figure 1 on th e next page). The information whether a patent is $r$ elated to any of the four classes can be gleaned from the Patent Classification Number. Further analysis of the referenced patents shows a similar pattern - references to circuits, devices, systems and s oftware. This appears to be a basis of the inventions within the semiconductor industry, especially those $\mathrm{r}$ elated to the development of co mputer systems based on these systems, d evices and circuits. This is the basis of our more speculative investig ations related to the resonant tunneling systems.

\begin{tabular}{|c|c|c|c|c|}
\hline $\begin{array}{l}\text { Patent } \\
\text { No. }\end{array}$ & Freq. & $\begin{array}{l}\text { Compound } \\
\text { Term }\end{array}$ & Freq. & $\begin{array}{c}\text { Compound } \\
\text { Term }\end{array}$ \\
\hline & $\begin{array}{l}\text { Mem- } \\
\text { ory }\end{array}$ & Cell (m.c.) & $\begin{array}{l}\text { Mem- } \\
\text { ory }\end{array}$ & Device (m.d.) \\
\hline 6567330 & 4 & & 3 & $\begin{array}{l}\text { semicond. } \\
+ \text { m.d.(3) }\end{array}$ \\
\hline 6407946 & 2 & $\begin{array}{l}\text { m.c. } \\
+ \text { transistor }(2)\end{array}$ & 1 & $\begin{array}{l}\text { non-volatile } \\
\text { semicond. } \\
+ \text { m.d.(1) }\end{array}$ \\
\hline 6337825 & & & 2 & $\begin{array}{l}\text { semicond. } \\
+ \text { m.d.(2) }\end{array}$ \\
\hline 6219290 & 3 & $\begin{array}{l}\text { m.c. }+ \text { sense } \\
\text { amplifier (1) }\end{array}$ & & \\
\hline \multicolumn{5}{|l|}{6205073} \\
\hline 6038169 & 3 & $\begin{array}{l}\text { flash }+ \text { m.c. } \\
(1) ; \text { m.c. cur- } \\
\text { rent }(2)\end{array}$ & & \\
\hline 5910914 & 2 & & 2 & $\begin{array}{l}\text { Floating gate } \\
+ \\
\text { m.d. (2) }\end{array}$ \\
\hline 5742543 & 3 & & & $\begin{array}{l}\text { flash + m.d. } \\
\text { (1) }\end{array}$ \\
\hline 5386388 & 1 & & & \\
\hline Total & 18 & & 9 & \\
\hline
\end{tabular}

Table 5. Distribution of the two co-cited terms in the nine patents. The frequency of the compound terms is included in the frequency count.

${ }^{2}$ From http://www.mic ron.com/, site visited 29 May 2003 


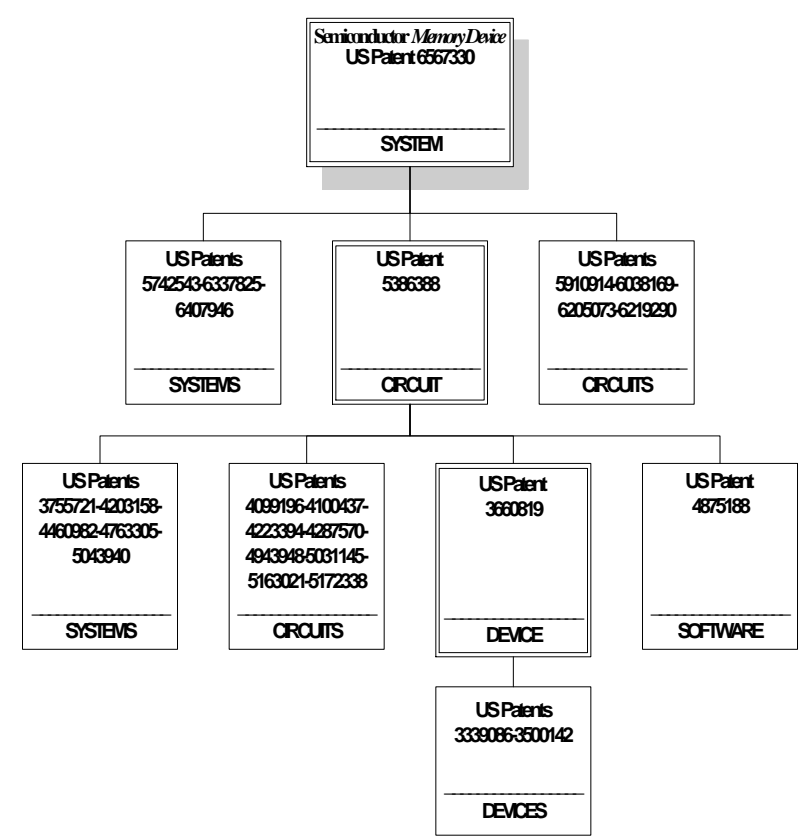

Figure 1: A hierarchical citation -based ordering of patents and the distribution of patents into three categories - systems, circuits and devices.

\section{The Evolution of the Resonant Tunneling Devices}

We will now focus on how terminology u sage may help in tracking the evolution of resonant tunne ling devices. These are ultra high-speed devices, which perhaps will be used in the compute rs of the next decade or so. In order to study how one can track technology progress we have adopted an i ntuitive, but realistic, framework. For us, all co mplex systems comprise subsystems and subsystems are made up of much smaller (and simpler) $d e$ vices. A computer system is made up of i ntegrated circuits and the circuits made up of transistors and transistors come in different types. One model of growth can be thought of as follows: First, devices are patented, then subsystems, and finally the complex systems (remember only tangible articles can be patented). So following this intuitive framework we will first see a number of devices being patented then subsystems and finally the sy stems themselves. Tunnel diodes are supposed to empower faster switching devices, which in turn have to be incorporated into subsystems with tu nneling transistors and into complex systems with circuits. Our hypothesis is that an analysis of a diachronically organized text corpus will show the working of the above-mentioned framework.

A corpus was built containing more than 2.2 million words of patent documents. The co rpus contains all patent documents that co ntain the term tunneling in the title. USPTO search r esults showed that there are 372 titles, approved from 1975 to 1999 in semiconductor physics. We have analysed frequency of compound word in the USPTO patent documents published $\mathrm{b}$ etween 1975-1999 (Table 6).

\begin{tabular}{|l|r|r|r|r|r|}
\hline & $75-79$ & $80-84$ & $85-89$ & $90-94$ & $95-99$ \\
\hline $\begin{array}{l}\text { No.of } \\
\text { Texts }\end{array}$ & 7 & 8 & 68 & 133 & 156 \\
\hline $\begin{array}{l}\text { Total No. } \\
\text { of tokens }\end{array}$ & 43812 & 43262 & 378272 & 771525 & 995894 \\
\hline
\end{tabular}

Table 6. The diachronic breakdown of patents comprising at least one instance of the token tunneling over 5 year intervals between 1975 -1999.

The compound word analysis was co nducted using System Quirk and no compounds were pre specified (System Quirk a text analysis system, is available on www.computing.surrey.ac.uk/ai/SystemQ ). The system extracts compound words based on a si mple heuristic: a set of word that does not co ntain closed class w ords (i.e. determiners, conjun ctions, prepositions, and moderators) or the orthographic signs (including punctuation, numbers, currency and other symbols) is considered by Sy stem Quirk to be a compound word (see Ahmad and Rogers, 2001 , for details). The validation of compound words can also be carried out by statistical tests, for instance described by Smajda (1994).

To investigate the progress of resonant tunneling devices and circuits, the multi-word terms were extracted from the USPTO full text corpus using System Quirk. The extracted terms that relate to resonant tu nneling diodes, resonant tunneling transistors and resonant tunneling ci rcuits were arranged in a five year interval starting from the first emergence of the term resonant tunneling in USPTO a bstract documents in 1985.

Tracking the frequency usage of the terms associated with resonant tunneling artefacts in the USPTO full text corpus shows a considerable i n- 
crease of frequency usage i nterval by interval. The frequency of the term resonant tunneling diode (and its plural form resonant tunneling diodes, both denoted as the lemma resonant tunneling $d i$ ode subsequently) increased significantly from 45 in 1985-1989 to 446 in $1990-1994$ by about a factor of 19 and then in the next time interval 1995 . 1999 the frequency dropped by about half to 240 . The frequency usage of the term resonant tunneling transistor in the USPTO full text corpus i ncreased from 23 in the period 1985-1989 by about a factor of 10 to 225 in $1990-1994$. The increase of frequency usage of the term in the time period 1995-1999 increased by a factor of 1.3 to become 293. The term resonant tunne ling circuit appears in the USPTO full text co rpus 45 times in the time interval 1990-1994. Frequency usage of resonant tunneling circuits inc reased by a factor of 1.3 in the next interval (1995-1999) to 57.

Word formation is not restricted to the i nflection of a compound word. Rather, we see fu rther instances of compounding where an existing compound, say, resonant tunneling $d i$ ode/transistor is used as a head of other co mpounds (Table 7).

\begin{tabular}{|l|l|}
\hline \multicolumn{1}{|c|}{$1990-1994$} & \multicolumn{1}{|c|}{$1995-1999$} \\
\hline $\begin{array}{l}\text { barrier resonant tunne l- } \\
\text { ing diode }\end{array}$ & $\begin{array}{l}\text { triple barrier resonant } \\
\text { tunneling diode }\end{array}$ \\
\hline $\begin{array}{l}\text { band resonant tunne ling } \\
\text { transistor }\end{array}$ & $\begin{array}{l}\text { bipolar quantum reso- } \\
\text { nant tunneling transi s- } \\
\text { tor }\end{array}$ \\
\hline
\end{tabular}

Table 7. The specialization, through prefixation, of the term resonant tunneling diode \& transistor over a 10 year period in our patent corpus

We note the very productive use of compoun ding and inflection in our corpus. Note, ho wever, that the size of the corpus for the three differe nt periods, 1985-89, 90-94 and 95-99, are different: 378272, 771525 and 995894 respectively. The size of the corpus perhaps for the later two $p$ eriods is roughly the same but the earlier corpus (85 -89) is three times smaller. In order to pr esent a better comparison we will look at the relative frequency of the compounds in that we will sum up the fr equency of all the extracted compounds related to resonant tunneling diodes, transistors and circuits, as per our intuitive fram ework, and assign relative frequency to each of the three relative to the sum.
Consider the result of analysis of 133 texts of patents published in 1990-1994 for tunnel diode related patents. The total number of terms co mprising the lemma resonant tunneling diode is 490 , which includes the lemma on its own and two terms containing the lemma as the headword; these are multiple peak resonant tunne ling diode, barrier resonant tunneling diode. The total containing the lemma resonant tunneling transistor is 225 , which is made up of 188 for the lemma on its own and the rest for the two other terms. The lemma $R T$ circuit also includes hyponyms of the term, e.g. RT oscillator (circuit), RT logic gate (circuit) and RT memory (circuit); note that the term circuit is shown in parentheses as it is ellipsed in the text - the reader of the patents, an expert in the disc ipline, is expected to know that an oscillator is a circuit. The two terms occur 24 and 12 times t ogether with 4 other terms that collectively occur 9 times ma king a total of 45 . The three lemmas $R T$ diode, transistor and circuit occur for a total of $490+225$ $+45(=760)$ times, hence the relative fr equency of the three lemmas is $64.4 \%$ (490/760), $29.6 \%$ (225/760) and 6\% (45/760) respectively (Table 8 shows a breakdown of the distributio n).

This relative frequency computation was conducted over the periods $1985-1989$ and 1995 1999. Table 9 (on the next page) shows that over $64 \%$ of the terms belong to the lemma resonant tunneling diode $\sim$, about $30 \%$ to resonant tunne ling transistor and just about $6 \%$ to resonant tu nneling circuit $\sim$. This situation changes quite dramatically in the next quinquennium (1995-1999). 


\begin{tabular}{|c|c|c|c|}
\hline Artefact & 1990-1994 & Freq & $\%$ \\
\hline \multirow{3}{*}{$\begin{array}{l}\text { Resonant } \\
\text { tunneling } \\
\text { diodes }\end{array}$} & resonant tunneling diode & 446 & \\
\hline & $\begin{array}{l}\text { multiple peak resonant tunneling } \\
\text { diode }\end{array}$ & 24 & \\
\hline & barrier resonant tunneling diode & 20 & \\
\hline Total & & \multicolumn{2}{|c|}{$49064.4 \%$} \\
\hline \multirow{3}{*}{$\begin{array}{l}\text { Resonant } \\
\text { tunneling } \\
\text { transistors }\end{array}$} & resonant tunneling transistor $\sim$ & 188 & \\
\hline & band resonant tunneling transistor $\sim$ & 35 & \\
\hline & $\begin{array}{l}\text { bipolar quantum resonant tunneling } \\
\text { transistor } \sim\end{array}$ & 2 & \\
\hline Total & & \multicolumn{2}{|c|}{$22529.6 \%$} \\
\hline \multirow{6}{*}{$\begin{array}{l}\text { Resonant } \\
\text { tunneling } \\
\text { 'Circuit ' }\end{array}$} & resonant tunneling oscillator & 24 & \\
\hline & resonant tunneling logic gate & 12 & \\
\hline & resonant tunneling diode memory & 3 & \\
\hline & resonant tunneling diode oscillator & 3 & \\
\hline & multiple resonant tunneling circuits & 2 & \\
\hline & resonant tunneling photodetector & 1 & \\
\hline Total & & \multicolumn{2}{|c|}{$456 \%$} \\
\hline
\end{tabular}

Table 8: Resonant tunneling artefacts in the USPTO full text corpus in the time period 1990 1994.

\begin{tabular}{|c|c|c|c|}
\hline \multirow{2}{*}{ Compound term } & \multicolumn{3}{|c|}{ Period } \\
\hline & $85-89$ & $90-94$ & $95-99$ \\
\hline$R T$ diode $~$ & $66.2 \%$ & $64.4 \%$ & $41.2 \%$ \\
\hline$R T$ transistor $\sim$ & $33.8 \%$ & $29.6 \%$ & $49.1 \%$ \\
\hline$R T$ circuit & 0 & $6 \%$ & $9.7 \%$ \\
\hline Total & $100 \%$ & $100 \%$ & $100 \%$ \\
\hline
\end{tabular}

Table 9. The growth of compound terms compri sing the headwords diode \& diodes denoted colle ctively as diode $\sim$, transistor $\sim$, and circuit $\sim$, together with the stem resonant tunneling (RT).

\section{Afterword}

It appears that there is a local grammar, comprising vocabulary of the specialist domain and a sy ntax that appears different from the general (universal?) syntax, used in framing the claims, background and su mmary of the invention in a US Patent document. A number of slots in the US PTO document are reserved for proper na mes patentees, assignees, places of work, and other slots hold dates and all these slots show the e $\mathrm{x}$ tremes of the local grammar - essentially a gra mmar for a one-word language. The document comprises 'references to (other patents) and also citations to an extant by other later patents - this information is encoded in another local grammar of one or more 4 -tuples referring to a referenced patent - the 4-tuple has a clearly defined s equence and allows expressions only in terms of four noun phrases. The referenced patent number is an active hyperlink through which the details of the refe renced patent can be a ccessed and subsequently a chain of references can be established in a (semi -) automatic manner. The existence of a local gra mmar and the hyperlinks s uggests to us that one can create a historic (diachronic) description of an invention together with the crucial account of the influence of other inventions.

Restricted syntax is used, for example, in describing time (hours, minutes, seconds, days, years, months), in financial news wire as well as mission-critical communication. The specialist vocabulary, and more so the productive use of the vocabulary (see below for details), as well as the restricted syntax emerges initially for assuring a mbiguity-free communication in an inherent noisy medium of communication - natural language.

Complementary to the emergence of the present US patent document, there has been an a ccumulation of terminological knowledge in terms of the repositories usually referred to as patent classification. The Patent Offices around the world classify all manners of 'art icles' ranging from micro-electronics to kitchen utensils and from software systems to heavy excavation machinery, for example. Much like a number of other utilita $r-$ ian classification systems, including the Dewey Decimal Classification on the one hand and the US National Library of Medicine's Disease Classific ation system on the other, the US PTO classification system is detailed, complex, full of cross refe $r$ ences, and occasionally confusing. The fact $\mathrm{r}$ emains, however, that like all utilita rian systems, the US PTO classification system is a rich repository that can be used, with some alterations, as the lex ical/terminological resource for information extra ction in particular and NLP in general. The repository states the ontological commitment of the US PTO and its advisers, and can be used for building knowledge representation schema or s emantic processing sy stems.

The appearance of a local grammar, or perhaps local grammars, used to frame a patent document together with an extensive terminology database of patent class ification, is good news for the patent processing comm unity. There is some hope that the information extraction and NLP sy stems will be able to extract the terminology and identify the idiosyncratic syntax that governs the 
different parts of the patent document with the help of techniques pioneered in corpus linguistics. Terminology extraction can be facilitated by refe $r$ ring to the patent classific ation terminology base and facilitated by various statistical and linguisti c techniques used to identify complex noun -phrases in specialist texts. Once the local grammar is ide ntified it will be able to meaningfully process the documents for inferring the imp ort of a given invention in relation to other inventions and to assess the impact of journal publications of inventions. And, indeed all manner of new ways of examining a patent document may open up once the investig ator overcomes the burden of sifting th rough an overgrowing lexical mountain of new patents, rev isions to existing patents and the scientific and technical public ation juggernaut that adds more to the mountain on almost daily basis. The aut omatic extraction of compounds from a corpus of patent documents appears to show the introduction of new artifacts through the use of morphological processes like word formations. Cu rrently, our work in progress is to 'chart' a transfer of such terms in journal papers onto patents, in a ddition to the exercise reported which charts the transfer of terms within a diachronically organised corpus of patent doc uments.

\section{References}

Ahmad, K. 2000. Neologisms, Nonces and Word Fo rmation. Proceedings of the Ninth EURALEX Intern ational Congress (Munich August 2000).pp 71 1-729.

Ahmad, K. and Rogers, M. 2001. Corpus Lingui stics and Terminology Extraction. Handbook of Termino logy Management. Amsterdam: John Benjamins Pu blishing Co. pp725 -760.

Andersen, B. (2000). Technological change and the evolution of corporate patentin g: The structure of patenting 1890-1990. Cheltenham: Edward E lgar.

Appleyard, M.M. and G.A. Kalsow. 1999. 'Knowledge diffusion in semiconductor indu stry'. Journal of Knowledge Management. Volume 3 (No. 4). pp 288-295.

Effenberger, D. 1995. Fundamental s of Terminology Work. Computer Standards \& Interfaces, Vol. 17, 131-137.

Garfield, E.1995 The Impact of Cumulative Impact Fa ctors. Proceedings of the 8th IFSE Conference, Barc elona, pp58-81.
Gupta, V. K. and Pangannaya, N. B. 2000. Carbon Nanotubes: Bibli ometric Analysis of Patents. World Patent Information 22: 185 -189.

Meyer, M. 2001. Patent Citation Analysis in a Novel Field of Technology: An Exploration of Nano Science and Nano-Technology. Scientometrics 51.1:163-183.

Mogee, Mary E. (1997). 'Patent A nalysis Methods in Support of Licensing'. Paper presented at the Technology Transfer Society Annual Conference (De nver, USA). (http://www.mogee.com/services/tl methods.html, site visited $20 \mathrm{M}$ ay 2003).

Quirk, R, S Greenbaum, G Leech, J Svartvik. 1985. A Comprehensive Grammar of the En glish Language. London and New York: Lon gman

Smajda, F. 1994. 'Retrieving Collocations from Text: Xtract.'. In (Ed.) Susan Armstropng, U sing Large Corpora Ca mbridge, MA/London/England: MIT Press. pp $143-177$. 